\title{
DIKSI DAN GAYA KALIMAT DALAM NOVEL HAFALAN SHALAT DELISA KARYA TERE LIYE
}

\author{
Destriana Prastica ${ }^{1)}$, Yosi Wulandari ${ }^{2)}$ \\ ${ }^{1)}$, 2) Pendidikan Bahasa dan Sastra Indonesia \\ Fakultas Keguruan dan Ilmu Pendidikan \\ Universitas Ahmad Dahlan \\ Jalan Ringroad Selatan, Kragilan, Tamanan, Banguntapan, Bantul, Yogyakarta 55191 \\ ${ }^{1)}$ prasticadestriana@gmail.com, ${ }^{2}$ yosi.wulandari@pbsi.uad.ac.id
}

\begin{abstract}
ABSTRAK
Penelitian ini dilatarbelakangi karena ketertarikan akan keunikan penggunaan bahasa (diksi dan gaya kalimat) dalam novel Hafalan Shalat Delisa karya Tere Liye. Penelitian ini bertujuan untuk (1) mendeskripsikan diksi yang terdapat dalam novel Hafalan Shalat Delisa karya Tere Liye;dan (2) mendeskripsikan gaya kalimat yang terdapat dalam novel Hafalan Shalat Delisa karya Tere Liye. Jenis penelitian ini adalah penelitian deskriptif. Subjek penelitian ini adalah novel Hafalan Shalat Delisa karya Tere Liye, sedangkan objek penelitian ini adalah diksi dan gaya kalimat dalam novel Hafalan Shalat Delisa karya Tere Liye sebagai alternatif bahan ajar sastra di SMA. Metode pengumpulan data dilakukan dengan menggunakan teknik kepustakaan, simak/sadap, dan catat. Instrumen penelitian yang digunakan berupa teks novel Hafalan Shalat Delisa karya Tere Liye. Hasil penelitian ini sebagai berikut. (1) Diksi yang paling dominan digunakan dalam novel Hafalan Shalat Delisa karya Tere Liye adalah kata-kata asing yang diasumsikan sebagai gambaran kemampuan pengarang dalam penguasaan bahasa lain. (2) Gaya kalimat yang paling dominan digunakan dalam novel Hafalan Shalat Delisa karya Tere Liye adalah kalimat dengan sarana retorika, hal ini menunjukkan pengarang memanfaatkan sarana retorika agar pesan yang ingin disampaikan lewat cerita dapat diterima dan diinterpretasi oleh banyak dari berbagai sudut pandang.
\end{abstract}

Kata kunci: diksi, gaya kalimat, Hafalan Shalat Delisa, Tere Liye

\section{PENDAHULUAN}

Karya sastra merupakan bentuk ekspresi jiwa manusia yang dituangkan melalui tulisan. Tulisan tersebut ialah sebuah imajinasi yang berasal dari diri sendiri maupun lingkungan sekitar pengarang. Karya sastra dapat memberikan 
Destriana Prastica $^{\text {1) }}$, Yosi Wulandari ${ }^{2)}$ : Diksi dan Gaya Kalimat dalam Novel Hafalan Shalat Delisa Karya Tere Liye

Website : https://jurnal.umj.ac.id/index.php/penaliterasiEmail : penaliterasi@umj.ac.id

sinergi positif bagi pengarang sebab

pengarang akan

terlibat langsung dengan proses kreatif dalam penyusunan karya sastra. Selain itu, pengarang juga dapat menuangkan gagasan-gagasan dan pengalaman yang dirasakannya dengan menggunakan bahasa sebagai mediumnya.

Bahasa menjadi sebuah jembatan yang mampu menghubungkan dan menyampaikan pikiran-pikiran pengarang kepada pembaca. Pemakaian bahasa akan menunjukkan sebuah keunikan dalam karya sastra itu sendiri dan membuatnya menjadi lebih menarik karena pembaca karya sastra akan memainkan pikirannya untuk menemukan makna yang dimaksudkan oleh pengarang di dalam karyanya. Untuk memperoleh keefektivitasan pengungkapan dalam suatu karya sastra, seorang pengarang harus mampu mendayagunakan suatu kata atau kalimat dengan cermat untuk memperoleh efek estetis.

Berdasarkan uraian di atas, perlu diketahui penggunaan bahasa (diksi dan gaya kalimat) dalam karya sastra. Karya sastra yang dipilih berupa novel, yaitu novel Hafalan Shalat Delisa (HSD) karya Tere Liye. Novel tersebut menggunakan diksi yang beragam. Gaya kalimat yang digunakan pun mudah diterima oleh pembaca. Pemilihan diksi dan gaya kalimat ini benar-benar diperhatikan oleh pengarang sebab pengarang mengetahui bahwa hal itu akan memberikan nilai tersendiri baginya dan karyanya. Nilai yang diperoleh itu dapat berupa nilai estetis, yaitu keindahan yang akan mendayagunakan karya sastra itu sendiri.

Selain itu, Pradopo (1991:1) menyatakan bahwa nilai seni sastra sangat bergantung pada gaya bahasanya. Artinya pengatang dapat menentukan nilai seni karya yang dibuat berdasarkan gayanya. Jadi,

kemahiran sastrawan bermain stilistika dapat menentukan kepiawaian estetikanya.

Menurut Semi (1993: 82-83) terdapat beberapa hal yang harus diperhatikan dalam analisis stilistika, yaitu unsur yang ditentukan harus mencakup unsur keseluruhan karya, analisis struktural dengan kajian bahasa yang lebih dalam, sampai pada penjelasan makna, difokuskan pada corak individu penulis, analisis dapat diarahkan pada kalimat, paragraf, ataupun wacana, dan dapat pula dikaitkan dengan kajian resepsi sastra.

Al-Ma'aruf (2009: 47) menyatakan bahwa terdapat aspek-aspek stilistika, yang meliputi gaya bunyi (fonem), gaya kata (diksi), gaya kalimat, gaya wacana, bahasa figuratif, dan citraan. Akan tetapi, penelitian ini akan mengkaji aspek gaya kata (diksi) dan gaya kalimat.

Berdasarkan permasalahan yang telah dikemukakan, penelitian ini bertujuan untuk (1) mendeskripsikan diksi yang terdapat dalam novel $H S D$ karya Tere Liye; dan (2) mendeskripsikan gaya kalimat yang terdapat dalam novel $H S D$ karya Tere Liye; serta. Pengkajian mengenai diksi dan gaya kalimat ini akan dibahas menggunakan Teori Stilistika Ali Imron Al-Ma'aruf.

\section{METODE PENELITIAN}

Jenis penelitian ini adalah penelitian deskriptif. Metode pengumpulan data dilakukan dengan pembacaan novel, dilanjutkan dengan teknik simak, sadap, dan catat (Mahsun, 2007: 92-93). Instrumen penelitian yang digunakan berupa teks novel HSD karya Tere Liye. 
Destriana Prastica $^{\text {1) }}$, Yosi Wulandari ${ }^{2)}$ : Diksi dan Gaya Kalimat dalam Novel Hafalan Shalat Delisa Karya Tere Liye

Website : https://jurnal.umj.ac.id/index.php/penaliterasiEmail : penaliterasi@umj.ac.id

Teknik analisis data yang dilakukan meliputi pembacaan novel, penandaan kata, pencatatan data, pengklasifikasian data, mendeskripsikan

data berdasarkan tujuan penelitian, serta merumuskan kesimpulan.

\section{HASIL DAN PEMBAHASAN}

Berikut hasil penelitian diksi dan gaya kalimat dalam novel $H S D$ karya Tere Liye.

\section{Diksi}

Aspek-aspek diksi dalam novel $H S D$ karya Tere Liye ditunjukkan pada tabel berikut.

\section{Tabel 1}

Rekapitulasi aspek-aspek diksi dalam novel Hafalan Shalat Delisa karya Tere Liye

\begin{tabular}{|c|l|c|}
\hline No. & \multicolumn{1}{|c|}{ Aspek-Aspek Diksi } & $\begin{array}{c}\text { Jumlah } \\
\text { Frekuensi }\end{array}$ \\
\hline 1. & Kata konotatif & 13 \\
\hline 2. & Kata konkret & 15 \\
\hline 3. & $\begin{array}{l}\text { Kata sapaan khas dan nama } \\
\text { diri }\end{array}$ & 12 \\
\hline 4. & Kata asing & 29 \\
\hline 5. & $\begin{array}{l}\text { Kata dengan objek realitas } \\
\text { alam }\end{array}$ & 9 \\
\hline 6. & $\begin{array}{l}\text { Kosakata dari bahasa daerah } \\
\text { (Jawa) }\end{array}$ & 31 \\
\hline \multicolumn{2}{|c|}{ Jumlah } & $\mathbf{8 1}$ \\
\hline
\end{tabular}

\section{a. Kata Konotatif}

adalah kata yang memiliki makna tambahan yang terlepas dari makna harfiahnya. Berikut pembahasannya.

"Bumi menggeliat. Tarian kematian itu mencuat. Mengirimkan pertanda kelammanakutkan" (Liye, 2008: 66).

Bentuk 'bumi menggeliat' dan 'tarian kematian' memiliki konotasi suasana yang menyiratkan pertanda kelam dan menakutkan, bahwa akan terjadi sesuatu yang besar, yang akan meregang banyak nyawa. Penggunaan kata-kata konotatif tersebut membuat pembaca merasa

penasaran dengan kemungkinan-

kemungkinan peristiwa apa yang akan

terjadi karena situasi yang ditampilkan terasa sangat mencengkam dan mengerikan.

\section{b. Kata Konkret}

adalah kata yang dapat dilukiskan dengan tepat (memiliki makna harfiah). Berikut pembahasannya.

"Anak lelaki bergegas menjamah sarung dan kopiah. Anak gadis menjumput lipatan mukena putih dari atas meja. Bapak-bapak membuka pintu rumah menuju menasah. Ibu-ibu membimbing anak kecilnya bangun salat berjamaah" (Liye, 2008: 1).

Bentuk 'kopiah', 'mukena putih', 'menasah', dan 'salat' adalah kata-kata konkret yang berfungsi untuk melukiskan aktivitas warga Lhok Nga yang akan menjalankan salat Subuh di menasah. Dengan kata-kata konkret tersebut, pembaca dapat menemukan deskripsi bahwa warga Lhok Nga sangat religius dan taat beribadah.

\section{c. Kata Sapaan Khas dan Nama Diri}

merupakan kata yang dipakai untuk menyebut diri seseorang. Berikut pembahasannya.

"HAIYA, kalau begitu kalungnya separuh harga saja Umi Salamah!” Koh Acan tersenyum riang" (Liye, 2008: 19).

Kata sapaan khas 'Koh' pada 'Koh Acan' merupakan kata serapan dari bahasa Cina yang berarti 'kakak laki-laki'. Pengarang menggunakan kata tersebut untuk menunjukkan latar belakang Koh Acan yang merupakan keturunan Cina dan karakternya yang baik hati dan suka memberi. Hal itu juga menunjukkan hubungan kekerabatan dan kedekatan 
Destriana Prastica $^{\text {1) }}$, Yosi Wulandari ${ }^{2)}$ : Diksi dan Gaya Kalimat dalam Novel Hafalan Shalat Delisa Karya Tere Liye

Website : https://jurnal.umj.ac.id/index.php/penaliterasiEmail : penaliterasi@umj.ac.id

antartokoh, yaitu antara Umi Salamah dan

Koh Acan.

\section{d. Kata Asing}

yaitu kata yang diambil atau dipungut dari bahasa lain, baik bahasa asing maupun bahasa daerah. Berikut pembahasannya.

Cara berpikir Delisa amat lateral. Ia berpikir dengan cara yang berbeda (Liye, 2008: 12).

Kata 'lateral' merupakan kata serapan bahasa Inggris yang berarti di sebelah sisi/cabang. Pemakaian kata tersebut lebih efektif dan menarik karena dapat menggambarkan cara berpikir Delisa yang cerdas, dengan melihat sesuatu tidak hanya dari satu sisi. Artinya, Delisa merupakan seorang yang penuh pertimbangan, yaitu berpikir dahulu sebelum bertindak (melakukan sesuatu hal).

\section{e. Kata dengan Objek Realitas Alam}

yaitu kata yang memanfaatkan realitas alam sebagai bentukan kata tertentu yang memiliki arti. Berikut pembahasannya.

Mereka tinggal di kompleks perumahan sederhana. Dekat sekali dengan tubir pantai. Lhok Nga memang tepat di tepi pantai. Pantai yang indah. Rumah mereka paling berjarak empat ratus meter dari bibir pantai (Liye, 2008: 10).

Bentuk 'tubir pantai', 'tepi pantai', 'pantai yang indah', dan 'bibir pantai' merupakan kata-kata yang digunakan untuk menunjukkan tempat tinggal tokoh yang sederhana dan dekat dengan pantai, dengan mengambil realitas alam untuk menggambarkan keadaannya.

\section{f. Kosakata dari Bahasa Daerah (Jawa)}

berguna untuk menciptakan efek makna tertentu dan menciptakan latar sosial budaya masyarakat daerah. Berikut pembahasannya.
Meski barusan habis menatap tajam Aisyah, suara Ummi terdengar sumringah sekali ketika mengangkat telepon itu (Liye, 2008: 29).

Kata 'sumringah' dalam bahasa Jawa berarti 'bahagia'. Kata tersebut menunjukkan suasana kebahagiaan yang dirasakan oleh Umi ketika menerima telepon dari Abi. Pembaca dapat menemukan

deskripsi tentang perasaan Umi. Ada rasa bahagia bercampur haru pada saat itu karena tidak setiap saat Abi bisa menghubunginya.

\section{Gaya Kalimat}

Aspek-aspek gaya kalimat dalam novel $H S D$ karya Tere Liye ditunjukkan pada tabel berikut.

Tabel 2

Rekapitulasi aspek-aspek gaya kalimat dalam novel Hafalan Shalat Delisa karya Tere Liye

\begin{tabular}{|c|l|c|}
\hline No. & \multicolumn{1}{|c|}{$\begin{array}{c}\text { Aspek-Aspek Gaya } \\
\text { Kalimat }\end{array}$} & $\begin{array}{c}\text { Jumlah } \\
\text { Frekuensi }\end{array}$ \\
\hline 1. & Kalimat inversi & 6 \\
\hline 2. & Kalimat elips & 8 \\
\hline 3. & $\begin{array}{l}\text { Kalimat pendek dan } \\
\text { sederhana }\end{array}$ & 6 \\
\hline 4. & Kata asing & 5 \\
\hline 5. & $\begin{array}{l}\text { Penggunaan konjungsi pada } \\
\text { awal kalimat }\end{array}$ & 28 \\
\hline 6. & $\begin{array}{l}\text { Kalimat dengan sarana } \\
\text { retorika }\end{array}$ & $\mathbf{6 9}$ \\
\hline & \multicolumn{1}{|c|}{ Jumlah } & \\
\hline
\end{tabular}

\section{a. Kalimat Inversi}

Kalimat inversi adalah gaya bahasa kalimat dengan membalik susunan subjekpredikat menjadi predikat-subjek dalam kalimat. Berikut pembahasannya.

"Ais, kamu memangnya nggak bisa bangunin Delisa nggak pakai teriak-teriak apa?" (Liye, 2008: 2).

Kalimat di atas adalah bentuk kalimat inversi yang digunakan untuk menekankan gagasan mengenai karakter Aisyah yang 
Destriana Prastica $^{\text {1) }}$, Yosi Wulandari ${ }^{2)}$ : Diksi dan Gaya Kalimat dalam Novel Hafalan Shalat Delisa Karya Tere Liye

Website : https://jurnal.umj.ac.id/index.php/penaliterasiEmail : penaliterasi@umj.ac.id

kurang sabar dalam menghadapi Delisa karena kebiasaan adiknya yang susah dibangunkan ketika tidur, serta karakter Fatimah sebagai kakak sulung yang pengertian dan lemah lembut.

\section{b. Kalimat Elips}

kalimat elips adalah gaya bahasa dengan menghilangkan unsur tertentu dalam kalimat yang dengan mudah diisi atau ditafsirkan sendiri oleh pembaca sehingga struktur gramatikalnya memenuhi pola yang berlaku. Berikut pembahasannya.

Aisyah hanya menggerakkan hidung dan bibirnya. Menyeringai tak peduli. Fatimah malah ketawa melihatnya; urung melanjutkan omelan (Liye, 2008: 23).

Kalimat di atas mengalami elipsis dengan tidak adanya subjek (Aisyah). Jadi, mestinya kalimat itu lengkapnya adalah 'Aisyah hanya menggerakkan hidung dan bibirnya. Aisyah menyeringai tak peduli'. Dengan subjek yang dielipsiskan, mampu menciptakan efek yang menunjukkan tingkah laku Aisyah yang sedang kesal serta karakter Fatimah yang penyabar. Fatimah seorang kakak yang dapat mencairkan suasana dengan melihat suasana hati adiknya.

\section{c. Kalimat Pendek dan Sederhana}

Kalimat pendek dan sederhana adalah kalimat yang hanya terdiri atas subjek dan predikat, yang dimaksudkan untuk mencapai efektivitas kalimat dengan mencapai makna tertentu. Berikut pembahasannya.

Koh Acan tersenyum getir. Menahan tangis. Menggeleng (Liye, 2008: 119).

Kalimat di atas merupakan kalimat pendek dan efektif, yang menyampaikan makna kesedihan yang dialami oleh Koh Acan karena telah kehilangan istrinya akibat bencana tsunami. Pembaca menemukan deskripsi bahwa Koh Acan seorang yang tegar, kuat, dan berusaha menutupi kesedihannya, meskipun sebenarnya hatinya sedang dirundung duka yang mendalam.

\section{d. Kalimat Majemuk}

Kalimat majemuk adalah pemanfaatan kalimat yang terdiri atas dua klausa atau lebih, baik majemuk setara maupun bertingkat. Berikut pembahasannya.

Mereka berdua saja yang nggak pernah cocok. Satu nggak pernah merasa suara itu cukup keras, satu lagi nggak pernah merasa suara itu cukup kedengaran (Liye, 2008: 9).

Kalimat di atas merupakan kalimat majemuk bertingkat dengan tiga klausa, terdiri atas induk kalimat 'Mereka berdua saja yang nggak pernah cocok'; anak kalimat (1) 'Satu nggak pernah merasa suara itu cukup keras'; dan anak kalimat (2) 'satu lagi nggak pernah merasa suara itu cukup kedengaran'. Pemanfaatan variasi panjang tersebut bertujuan untuk mencapai efek makna yang menunjukkan adanya ketidakcocokan antara Aisyah dan Delisa, meskipun keduanya adalah kakak-beradik.

\section{e. Penggunaan Konjungsi pada Awal Kalimat}

Penggunaan konjungsi pada awal kalimat merupakan suatu penyimpangan kaidah bahasa Indonesia yang sengaja dilakukan untuk menekankan gagasan tertentu. Berikut pembahasannya.

Tadi siang ketika di sekolah, pas pelajaran agama, Pak Guru Jamal bilang begini: Boleh jadi saudara-saudara kita akan menjadi tameng api neraka. Maka berbuat baiklah kepada mereka (Liye, 2008: 49).

Penggunaan konjungsi 'Maka' merupakan bentuk penyimpangan struktur 
Destriana Prastica $^{\text {1) }}$, Yosi Wulandari ${ }^{2)}$ : Diksi dan Gaya Kalimat dalam Novel Hafalan Shalat Delisa Karya Tere Liye

Website : https://jurnal.umj.ac.id/index.php/penaliterasiEmail : penaliterasi@umj.ac.id

kalimat dengan tujuan untuk menegaskan perkataan (nasihat) Pak Guru Jamal untuk berbuat baik kepada sesama manusia.

\section{f. Kalimat dengan Sarana Retorika}

Kalimat sarana retorika menunjukkan variasi yang beragam dalam suatu kalimat untuk mencapai efek makna tertentu yang efektif, indah, dan kaya nuansa. Berikut pembahasannya.

“S-a-t-u!" Fatimah mulai menghitung. “Du-a!" Yang diancam tetap tidak bergerak. “T-i-g-a!” Fatimah sambil tersenyum mulai menggerayangi perut, ketiak, dan telapak kakinya (Liye, 2008: 3).

Bentuk 'satu, dua, dan tiga' menggunakan gaya kalimat klimaks dengan

menunjukkan angka yang semakin meningkat. Kalimat klimaks dimanfaatkan secara plastis untuk menegaskan maksud dan gagasan yang bersifat mengancam. Hal tersebut dilakukan Fatimah untuk membangunkan Delisa supaya ia cepat terbangun karena Delisa seorang yang sulit dibangunkan kalau tidur.

\section{PENUTUP}

Berdasarkan hasil analisis dan pembahasan dapat disimpulkan bahwa diksi dan gaya kalimat dalam karya HSD menunjukkan karakteristik Tere Liye dalam menyampaikan maksud cerita. Gaya tersebut cenderung menggunakan gaya kata yang khas untuk menutupi maksud cerita dan memanfaatkan sarana retorika untuk mencapai efek estetis karya. Dengan demikian, gaya diksi yang ditemukan disini adalah diksi kata asing dan kalimat pemanfaatan saran retorika.

\section{REFERENSI}

Al-Ma'aruf, Ali Imron. 2010. Kajian Stilistika Perspektif Kritik Holistik: Analisis Trilogi Novel Ronggeng Dukuh Paruk Karya Ahmad Tohari. Surakarta: UNS Press.

. 2009. Stilistika: Teori, Metode, dan Aplikasi Pengkajian Estetika Bahasa. Suarakarta: CakraBooks Solo

Liye, Tere. 2008. Hafalan Shalat Delisa. Jakarta: Republika Penerbit.

Mahsun. 2007. Metode Penelitian Bahasa: Tahapan Strategi, Metode, dan Tekniknya. Jakarta: Rajawali Pers.

Pradopo, Rachmat Djoko. 1991. Pengkajian Puisi: Analisis Sastra Norma dan Analisis Struktural dan Semiotik. Yogyakarta: Gadjah Mada University Press.

Semi, Atar. 1993. Metode Penelitian Sastra. Bandung: Angkasa. 